\title{
APPROACHES TO THE STUDY OF CHENIERS ALONG THE COASTLINE OF THE SOVIET UNION
}

\author{
YURII D. SHUISKY \\ Department of Geography, Odessa State University, Odessa 270000 (U.S.S.R.)
}

(Received October 17, 1988; revised and accepted May 2, 1989)

\begin{abstract}
Shuisky, Y.D., 1989. Approaches to the study of cheniers along the coastline of the Soviet Union. In: P.G.E.F. Augustinus (Editor), Cheniers and Chenier Plains. Mar. Geol., 90: 289296.

With the very extensive coastline in the north and northeast and the relatively shorter coastlines in the south, cheniers in the USSR can occur in a great variety of climatological conditions ranging from subarctic to subtropical. Cheniers in the USSR have been studied since approximately 1900 , the investigations being mainly concerned with the palaeogeographical aspects. Since the 1960 's, investigations have focussed on contemporary morphodynamics. Chenier formation appears to depend largely on the relative influence that marine and fluvial factors have on the formation of marginal deltaic plains. Research in this feld is briefly reviewed.
\end{abstract}

\section{Historical background}

Geomorphological investigations of cheniers in the USSR have been carried out since the beginning of this century. Up to the 1940's cheniers were investigated as a part of a larger problem, i.e., the development of the estuarine areas of rivers. In the period between the 1940's and the 1950's however, they attracted much of attention with the development of new methods of defining and identifying global sealevel change. Interest in cheniers also grew with the development of navigation on the rivers (Zenkovitch, 1962). A review of some characteristic features of chenier development has been given by Zenkovitch et al. (1967); who for the first time studied chenier development in detail on the Danube delta (the Black Sea) (Fig.1).

Active interest in chenier investigations continued to grow between the 1960's and the 1980 's. During this period quite comprehensive data were obtained on the development of cheniers in the mouths of rivers such as the
Daugava, Don, Kuban, Northern Dvina, Pechora, Ural and Volga in the European Soviet Union (Fig.1). In the Asian Soviet Union, studies have been made on the Amu-Darya, $\mathrm{Ob}$, Pur and Yenisei Rivers and in the nearshore submarine areas (Fig.2). The long processes of initiation and development of river mouths and the development and contemporary morphology of cheniers since the pre-Holocene regression were mainly considered. Such regional investigations enabled the examination of chenier plains under differing environmental conditions.

The term "chenier" is new to Soviet geomorphological literature, first appearing in Leontiev et al. (1975), and subsequently being included in Zenkovitch and Popov's (1980) reference book. Until that time, and indeed in most cases currently, the term "nearshore beach ridges" or "deltaic channel and breaker ridges" was used. Nearchannel and beach ridges are also distinguished. In the Danube delta they are locally called grindu. This 


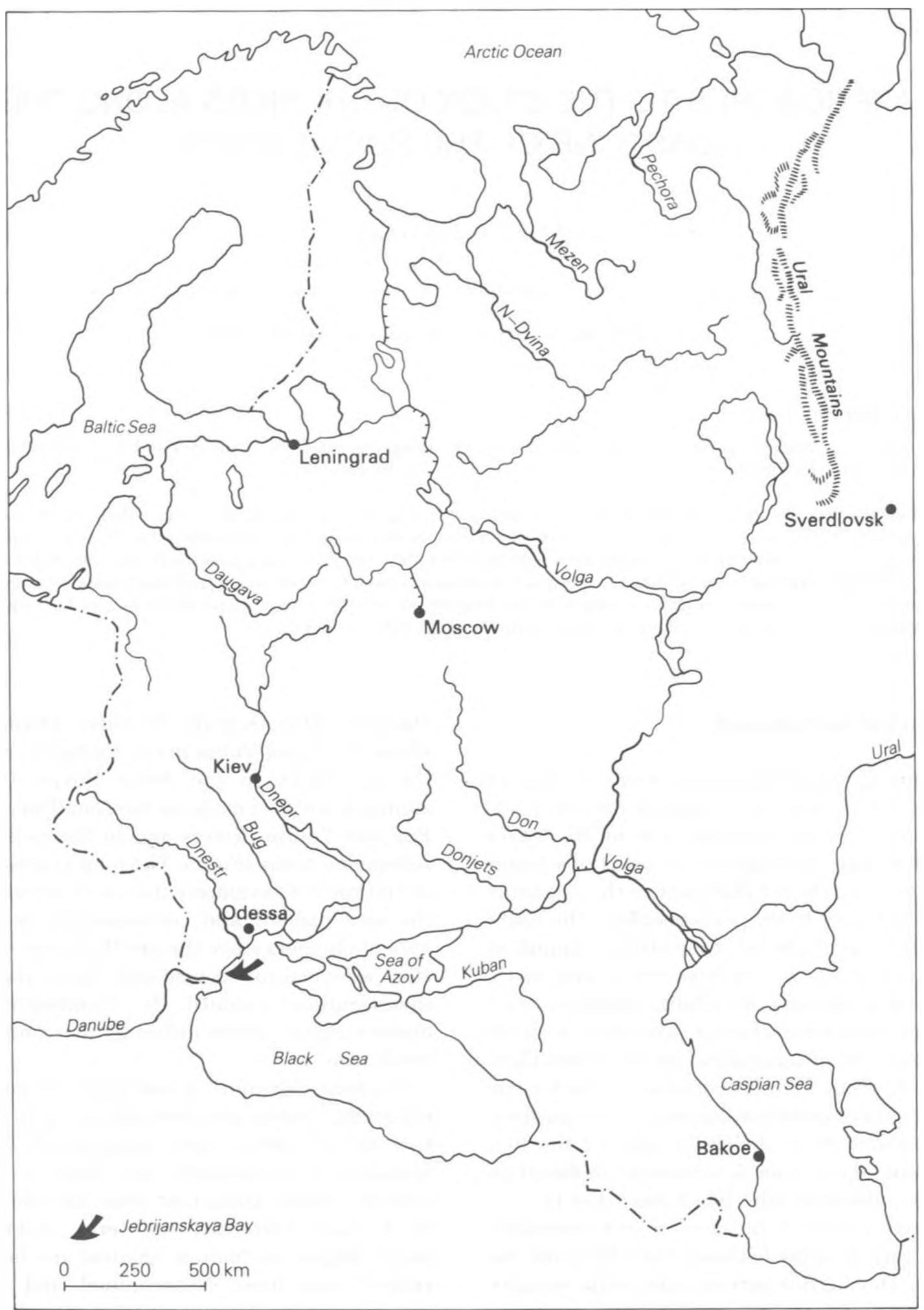

Fig.1. European Soviet Union, showing locations where cheniers have been studied. (See text for discussion.) 


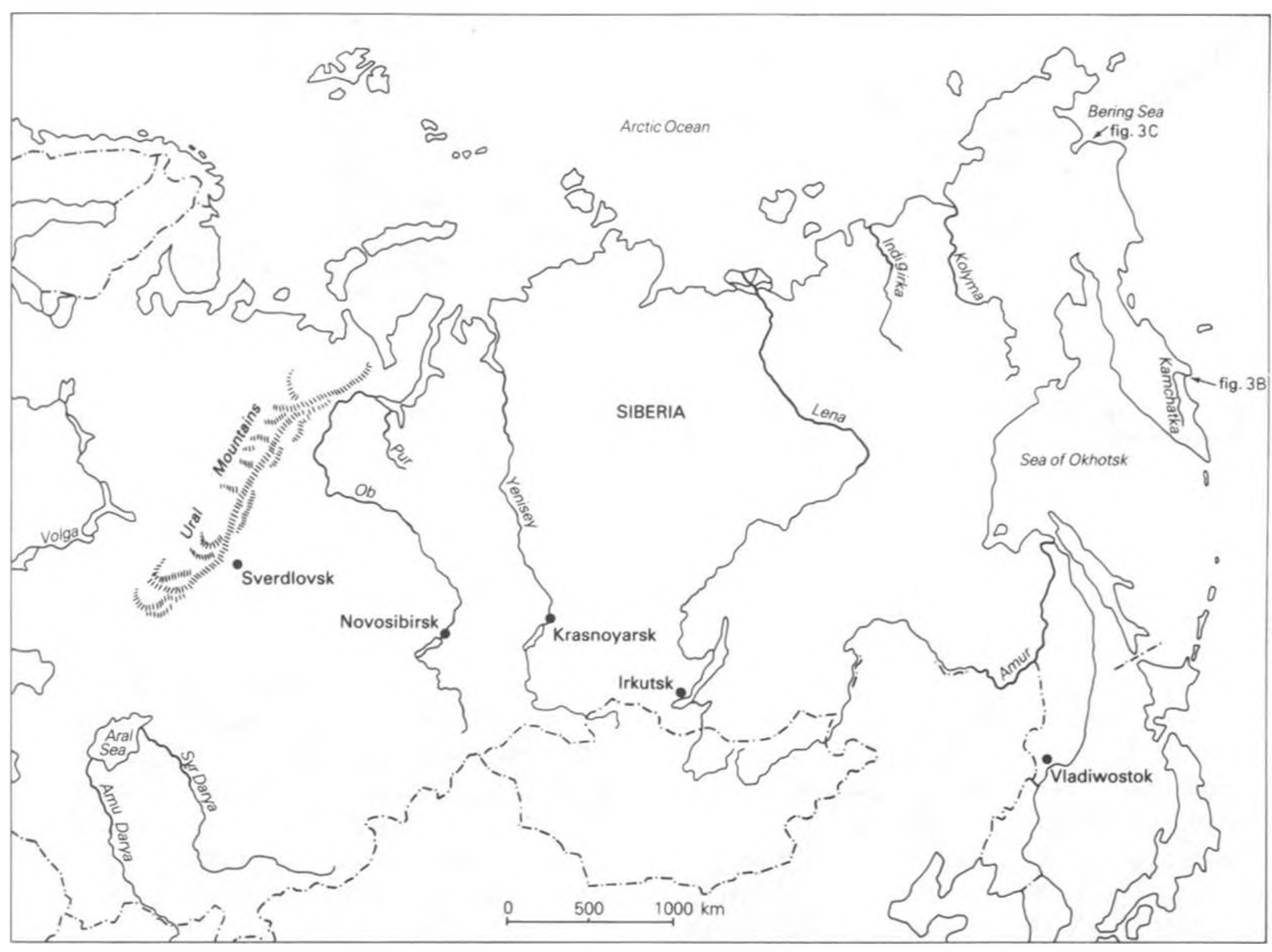

Fig.2. Asian Soviet Union, showing locations where cheniers have been studied. (See text for discussion.)

system of ridges, the chenier plain, is known in the Soviet literature as a coastal or deltaic terrace, features which usually have definite ages.

\section{Cheniers}

In this article the term 'chenier' should be understood as corresponding to the definition of Otvos and Price (1982). All of the examples were selected with this definition in mind. For example, the cheniers shown in Fig. 3 rest on mud or sandy mud. Their average height does not exceed 3.0-3.5 $\mathrm{m}$ and they have subfluvial, liman, lagoonal and deltaic origins. The ridges often branch out with a multitude of arms in a feathery, fan-like fashion and may bend landward or seaward.
Cheniers are more numerous and diverse in the USSR than in many other countries. Whilst this creates problems in the formulation of process and sedimentological models of chenier formation and makes primary analysis of the data somewhat slower, it does provide a more complete picture of the existing range of variation in chenier evolution and morphology. Studies of the Holocene depositional history of river- and seashore plains and terraces continue to be vigorously pursued in the USSR.

In the 1960 's, investigations began into the contemporary processes of chenier development. This was due largely to the work of Samoilov (1952). In the mouths of a number of large rivers (in particular in the Danube, Daugava, Don, Volga and Kuban) (Fig.1), moni- 

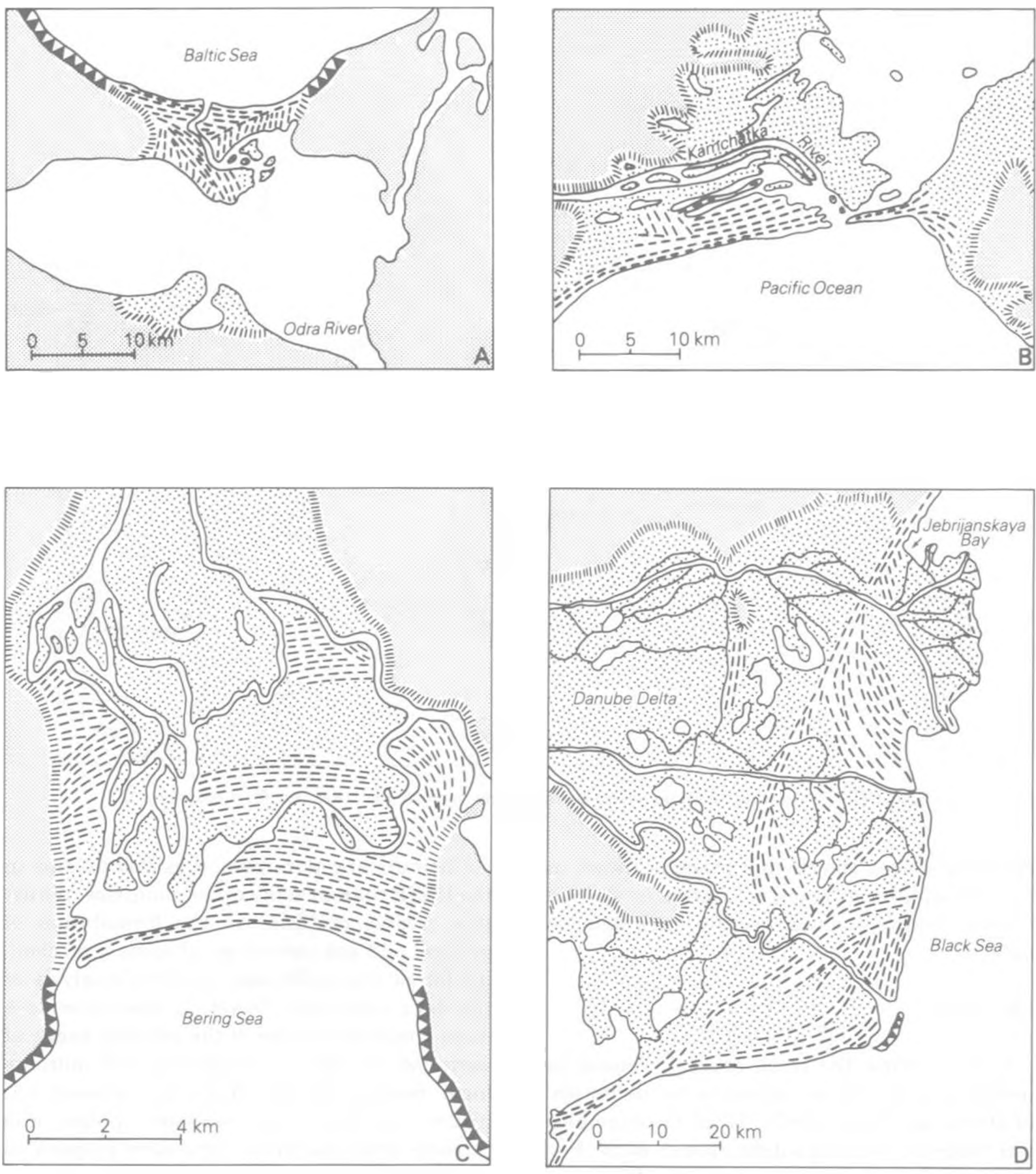

margin of original and alluvial relief forms

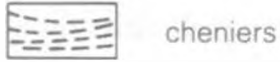

active cliffs on sea coasts

coastal and alluvial sediments

Fig.3. Examples of cheniers distribution in different geomorphological conditions. A. Mouth of the Odra River. Baltic Sea. B. Mouth of the Kamchatka River. Pacific Ocean. C. Filling of the head of one of the Bering Sea bays with drifts. D. Delta of the Danube River (the arrow indicates the location of the region in Fig.4). 
toring was organized and large scale maps were drawn and compared with those made during the last 150-200 years.

Such interest in contemporary processes was further stimulated by Mikhailov's (1971) work on the coastal zone. This led to the Academy of Sciences organizing, for the first time in the USSR, a scientific section studying river estuaries and seashores.

Up to now there have been two main trends in chenier research in the USSR - palaeogeographical and contemporary morphodynamics. This article deals mainly with the second trend.

\section{The process of chenier formation}

\section{General concept}

To understand the processes of chenier evolution it is necessary to make empirical observations to aid the reconstruction of the formation of deltaic ridges, estuarine ridges, and beach ridges situated beyond the limits of the river mouth. In the interpretation of such investigations, environmental conditions must also be taken into account. Comparison of large-scale maps drawn at different times and laboratory experiments are of secondary importance. Sediment discharge from the river, the width of the river mouth where it enters the sea, the offshore slope, the quantity of coarse-grained littoral sediment supply, nearshore bottom characteristics and, in sections contiguous with the non-deltaic shore, wave climate, all influence the evolution of chenier plains.

The role of each of the factors mentioned above, and also of a number of others, was analyzed by Mikhailov et al. (1986). As cheniers are formed on marine margins of deltas, the essential cause of chenier plain formation lies in the disturbance of the balance of fluvial and marine forces under the influence of the natural factors mentioned above. In this connection three main modes of delta progradation are distinguished: (1) those developing when fluvial factors prevail, (2) those formed when nearshore factors prevail, (3) those formed when intermediate factors prevail (Mikhailov et al., 1981).

Analysis of the evolutionary history of the three types of deltas has shown that prevalence of marine over fluvial factors was most favourable for chenier formation (Shuisky, 1984). The conditions of the intermediate type are less favourable. Fluctuations in the nearshore wave regime result in the formation of ridges on the flat offshore profile of the delta. These migrate over the swamped delta surface creating near-ridge dells, and causing the lengthening of large ridges and deltaic spits. Ridges and dells may be parallel to each other, fan-shaped, or may intersect at different angles. Such morphological elements may alternate: generations of fan-shaped cheniers may be followed by generations of parallel cheniers, etc. Each generation fixes one or another stage of development, and the change from one stage to another indicates the changes in the conditions of interaction between river and sea.

To give a quantitative average estimate of the relative influence of river and marine factors on the formation of marginal deltaic plains the following criteria are suggested (Mikhailov et al., 1981) (these take into account a number of factors):

(1) The average annual wave climate near the base of the deltaic cone evacuation $B_{m}$, and the flow of energy depending on the average wave height $h_{1}(\mathrm{~m})$, the group velocity of the waves $C_{n}(\mathrm{~m} / \mathrm{s})$ and recurrence of different heights of waves coming from different points of the marine sector of the horizon (\%).

(2) The average annual fluvial sediment yield $R(\mathrm{~kg} / \mathrm{s})$ related to a unit of the shoreline length of the delta $L_{\mathrm{og}}(\mathrm{m})$.

The higher the value of $R$ and the lower the value of $B_{\mathrm{m}}$ is the greater is the relative role of the river factors in the formation of the marginal deltaic plain. This allows us to evaluate processes of chenier formation on the flat shores of sea and oceans, in bays and in harbours, into which rivers with different sediment loads flow. The coefficient of sinuosity of the delta channels and the distance to 
which deltas project into the sea in relation to the general alignment of the contiguous shore is also taken into consideration.

\section{Review of case studies}

The well-studied delta of the Odra River flowing into the Baltic Sea is one of the classical examples (Fig.3A). When the mouth of this river emptied into the bay, cheniers were not formed. The same happened in the mouth of the Kamchatka River which flows into the Pacific Ocean (Fig.3B). In the mouth of a small river flowing into the Bering Sea conditions for chenier formation always existed during the middle and late Holocene. As the offshore slope, the wave regime, and the volume of fluvial sediment discharge changed, the development of generations of ridges of different orientation took place (Fig.3C). Gradually, sediment filled the bay and the shoreline grew towards the sea.

In the Danube delta also, cheniers have existed for a long time (Fig.3D). In the Soviet literature these, and some other examples, are explained with the help of the method of balance calculation (Shuisky, 1986). A theoretical investigation of the chenier forming processes in estuaries was carried out by Safianov (1987).

An investigation into chenier development is being carried out in the northern part of the Danube delta, in Jebrijanskaya bay (Figs.3D and 4). Longshore sediment transported from the northeast towards the delta is deposited here. Influenced by the refraction of sea waves and continuous shallowing of the bay (Shuisky, 1984), some sandy ridges move eastward from the general direction of the shoreline (Fig.4A). In the course of time the system of ridges will acquire the fanshape observed in during Holocene deposits in other parts of the Danube delta (Fig.3D).

During the stage of active growth the group of separate ridges (Fig.4B) forms a spit, with the rate of spit lengthening reaching 20-40 $\mathrm{m} / \mathrm{yr}$ under the local conditions. In the course of time, sediment supply to the end of the spit is reduced due to the formation of a new series of ridges and an increase in their size. These ridges form a new spit which blocks the sediment transport to the older spit. This is the reason why the old spit ceases to grow and remain in the form of a separate chenier. Under the local conditions the front part of the shore also may prograde with considerable speed, but more slowly than the lengthening of the spits, at $6-10 \mathrm{~m} / \mathrm{yr}$. In this case storm ridges join the shoreline (Fig.4B). Later they may produce spits, lying to the south of profile $\mathrm{A}-\mathrm{A}^{\prime}$. Figure 4 demonstrates a number of the dynamic parameters of chenier during their stages of active development over several decades.

During the 1970 's and 1980 's, a considerable number of investigations were carried out in the mouths of rivers flowing into the Arctic Ocean. Marine and river ice greatly influence the formation of large deltas of the Indigirka, Lena, Pur, Yenisei, and other rivers (Bogomo. lov et al., 1979; Korotaev 1981, 1983, 1984, 1986; Harrison et al., 1982; Babich et al., 1983; Polonsky, 1984) as well as the mouths of small rivers (Kuraeva, 1984) (Fig.2). All estuaries differ in the balance of marine and fluvial forces they are exposed to. Since many of the rivers on the coast of the Arctic Ocean flow into bays and harbours, and the nearshore water area is covered with ice for up to $70-80 \%$ of the year, these Arctic Ocean deltas are mainly fluvially dominated. This results in weak chenier development. During the investigation of the estuaries of the northern rivers, a great deal of attention was given to the Holocene history (Harrison et al., 1982; Korotaev, 1984; Polonsky, 1984). Contemporary processes during the last $100-200$ years were studied in much less detail. The main focus of studies on the shores of the southern and eastern seas of the USSR is on contemporary processes of chenier formation, e.g. the work in the delta of the Kuban river (Sea of Azov) (Bogucharskov and Ivanov, 1979). In these studies sections of retreat and growth of deltas in relation to the marine and fluvial factors, and mechanisms of sediment distribution, have 

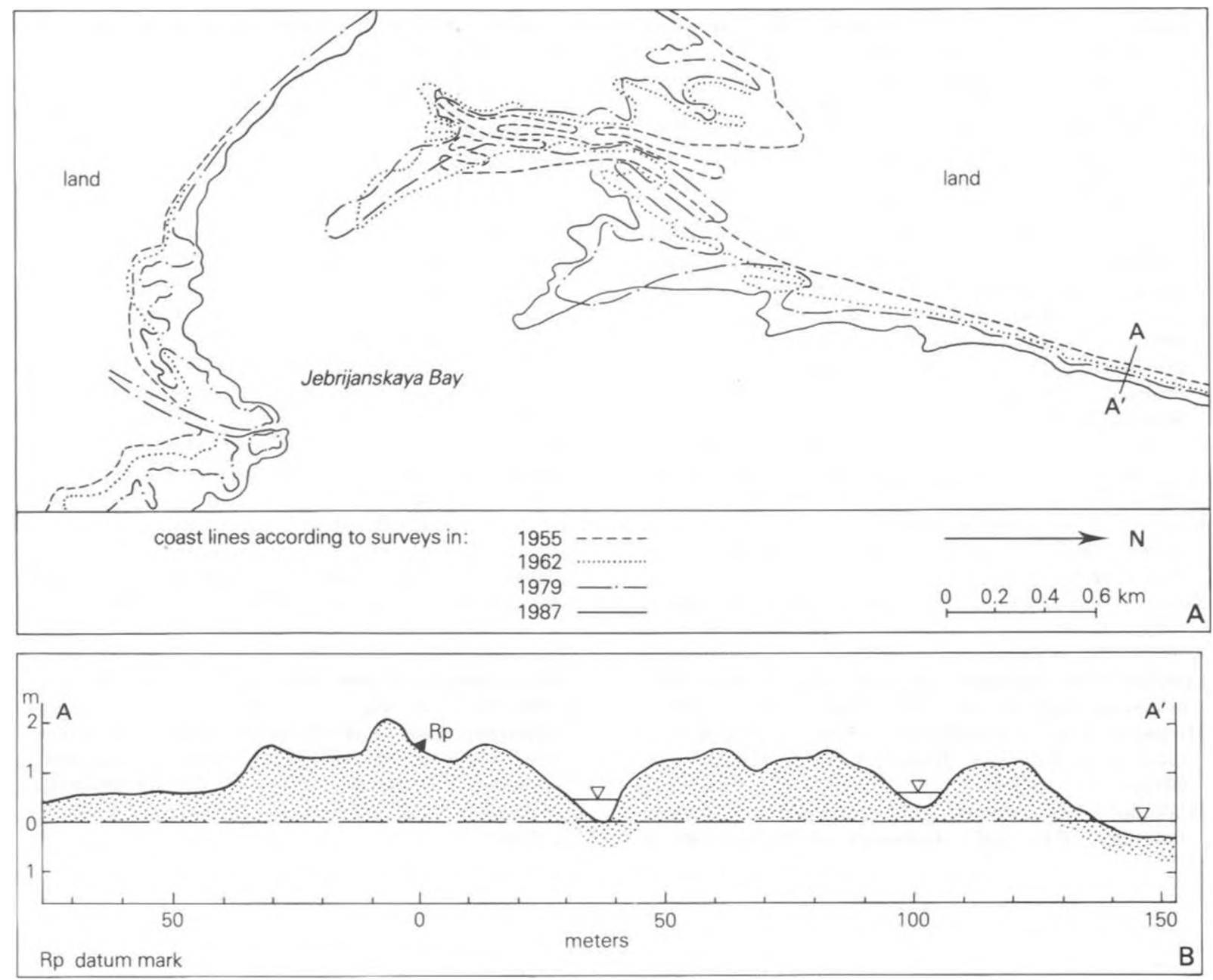

Fig.4. Development of contemporary cheniers in Jebrijanskaya bay (see Fig.3D) for wider location). A. Location of the coastline during different surveys. $\mathrm{B}$. Profile $\mathrm{A}-\mathrm{A}^{\prime}$.

been considered in detail. This has provided opportunity to determine contemporary rates of chenier and chenier plain formation. A summary of the results of the investigation of some natural processes in non-tidal estuaries is given in Mikhailov et al. (1977).

\section{Conclusion}

Considerable attention has been paid to the problem of cheniers in the USSR. The recent trend of investigations into contemporary processes of the formation of ridges of sea and submarine origin, and the contribution of aeolian, biogenic and anthropogenic factors must be considered most timely. This will aid the understanding of the Holocene evolution of cheniers and chenier plains.

\section{References}

Babich, D.B., Bogomolov, A.L., Zaets, G.M., Korotaev, V.N., Lodina, R.V., Mikhailov, V.N., Sidorchuk, A.Y. and Chalov, R.S., 1983. Contemporary processes of delta formation and stages of development of the delta of the Yenisei River. In: R.S. Chalov (Editor), Soil Erosion and River-bed Processes. Moscow Univ. Publ., Moscow. Vol.9, pp.183-201.

Bogomolov, A.L., Zaets, G.M., Korotaev, V.N., Lodina, R.V., Miloshevitch. V.A., Mikhinov, A.E., Sidorchuk, A.Y. and Chalov. R.C., 1979. Basic processes forming the delta of the Indigirka River. In: L.G. Nikiforov and B.G. 
Fiodorov (Editors), Soil Erosion and River-bed Processes. Moscow Univ. Publ., Moscow, pp.146-159.

Bogucharskov, V.T. and Ivanov, A.A., 1979. The Kuban Delta. Rostov Univ. Publ., Rostov, 108 pp.

Harrison, L.M., Korotaev, V.N. and Sidorchuk, A.Y., 1982. Paleomorphological analysis of the delta plain of the Yenisei River. Herald Moscow Univ., Geogr. Ser., 6: $103-109$.

Korotaev, V.N., 1981. Development of river deltas in the north of Siberia. In: N.I. Makkaveev and R.S. Chalov (Editors), Soil Erosion and River-bed Processes. Moscow Univ. Publ., Moscow, pp.157-173.

Korotaev, V.N., 1983. Stages of filling of the estuary of the Pur River in the Holocene. In: A.I. Spiridonov (Editor), Problerns of Morphodynamics. Geogr. Soc. USSR Publ., Moscow, pp.39-47.

Korotaev, V.N., 1984. Development of the hydrographical system in the delta of the Lena River in the Holocene. Herald Moscow Univ., Geogr. Ser., 6: $39-44$.

Korotaev, V.N., 1986. Geomorphology of river deltas of Arctic coasts of Siberia. Herald Moscow Univ., Geogr. Ser., 1: 42-49.

Kuraeva, L.N., 1984. Peculiarities of the hydrological regime in the estuarine area of the Kemi and Vygi Rivers. Trans. Oceanogr. Inst., 172: 82-89.

Leontiev, O.K., Nikiforov, L.G. and Safianov, G.A., 1975. Geomorphology of Sea Coasts. Moscow Univ., $336 \mathrm{pp}$.

Mikhailov, V.N.. 1971. Dynamics of Flow and Bed in Nontidal River Estuaries. Hydrol. Liter. Publ., Moscow, $260 \mathrm{pp}$.

Mikhailov, V.N., Rogov, M.M., Makarova, T.A. and Polonsky, V.F., 1977. Dynamics of Hydrographical
Systems of Non-tidal river Estuaries. Hydrol. Liter. Publ., Moscow, 294 pp.

Mikhailov, V.N., Ivanov, A.N., Lyutikov, A.V. and Polonsky, V.F., 1981. Marine margin of deltas as the result of "river-sea" interaction. In: Coastal Zone. Nauka, Moscow, pp.26-32.

Mikhailov, V.N., Rogov, M.M. and Chistyakov, A.A., 1986. River deltas: hydrogeomorphological Processes. Hydrol. Liter. Publ., Leningrad, 280 pp.

Otvos, E.G. and Price, W.A., 1982. Cheniers and chenier plains. In: M.L. Schwartz (Editor), The Encyclopedia of Beaches and Coastal Environments. Dowden, Hutchinson and Ross, Stroudsburg, Pa., pp.206-207.

Polonsky, V.F., 1984. Distribution of water flow in the estuarine area of the Pechora River and changing trends. Trans. Oceanogr. Inst., 172: 96110.

Safianov, G.A., 1987. Estuaries. Mys., Moscow, 189 pp.

Samoilov, I.V., 1952. River Estuaries. Geogr. Liter. Publ., Moscow, 526 pp.

Shuisky, Y.D., 1984. Dynamics of the marine margin of Kyliadelta of the Danube. Trans. Oceanogr. Inst., 172: 50-58.

Shuisky, Y.D., 1986. Problems of Drift Balance Investiga tion in the Coastal Zone. Hydrol. Liter. Publ., Leningrad, $240 \mathrm{pp}$.

Zenkovitch, V.P., 1962. Principles of Teaching on the Development of Coasts. Moscow Acad. Sci., 710 pp.

Zenkovitch, V.P. and Popov, B.A., 1980. Terminology Reference-Book: Marine Geomorphology. Coastal Zone: Processes, Concepts, Definitions. Mysl, Moscow, 280 pp. Zenkovitch, V.P., Kaplin, P.A., Ionin. A.S. and Medvediev, V.S., 1967. Coasts of the Pacific Ocean. Nauka, Moscow, $375 \mathrm{pp}$. 